whole approach to these disorders, so that lively and prospective management has replaced inertia and the chronic ward, and that in itself is worth while.

\section{Summary}

In opening a discussion on vertebro-basilar ischaemia, transient and reversible disturbances of cerebral and brain-stem function-" litttle strokes"-are attributed to reduction in the speed of blood flow, while both vascular spasm and thrombotic occlusion of small vessels are rejected as causal. Angiography shows that stenosis or occlusion of a large vessel may be remote from the resulting neural lesion, and that the haemodynamic properties of collateral flow may determine the pattern of disordered function and modify it in time. Precipitating factors, especially transient reduction in general or local bloodpressure, with preceding stenosis or occlusion, are largely causal. Many related changes in cardiovascular function may decide whether local flow is sufficiently reduced to cause transient symptoms.

The diagnosis of vertebro-basilar ischaemia depends on the association at any one time and from time to time of a number of apparently unrelated symptoms. The most common association is that of obscuration or other disorder of vision, with vertigo, ataxia, nausea, sensory changes, drop attacks, or loss of consciousness.

Investigation by angiography is reserved for special cases in the young; the results of treatment by vascular surgery have so far been disappointing; there is a place for the use of anticoagulants, but usually treatment is by general medical management.

\section{REFERENCES}

Alpers, B. J., and Berry, R. G. (1963). Arch. Neurol. (Chic.), 8, 398. Alpers, B. and Paddison, O. M. (1959). Ibid., 81, 409.

Biemond, A. (1951). Brain, 74, 300.

Brain, R. (1957). Lancet, 2, 857.

- (1963). Brit. med. F., 1, 771.

Byrom, F. B. (1954). Lancet, 2, 201.

Denny-Brown, D. (1951). Med. Clin. N. Amer., 35, 1457.

- (1953). Bull. New Engl. med. Cent., 15, 53.

Fields, W. S., Edwards, W. H., and Crawford, E. S. (1961). Arch Neurol. (Chic.), 4, 369.

Fletcher, T. M., Iaveras, J. M., and Pool, J. L. (1959). Ibid., 1, 38.

Groch, S. N., Hurowitz, L. J., and McDowell, F. (1960). Ibid., 2, 130.

Hallberg, O. E. (1957). 7. Amer. med. Ass., 165, 1649.

Hutchinson, E. C. (1962). In Modern Trends in Neurology, edited by D. Williams, p. 75. Butterworth, London.

- and Yates, P. O. (1956). Brain, 79, 319.

Kubik, C. S., and Adams, R. D. (1946). Ibid., 69, 73.

MacDonald, D. A. (1960). Blood Flow in Arteries. Arnold, London.

Meyer, J. S., Sheehan, S., and Bauer, R. B. (1960). Arch. Neurol. (Chic.), 2, 27.

Millikan, C. H., and Siekert, R. G. (1955). Proc. Mayo Clin., 30, 61

Pickering, G. W. (1955). High Blood Pressure. Churchill, London.

Pool, J. L. (1957). Arch. Neurol. (Chic.), 78, 355.

Riggs, H. E., and Rupp, C. (1963). Ibid., 8, 8.

Shaw, D. A. (1962). In Modern Trends in Neurology, edited by D. Williams, p. 108. Butterworth, London.

Sheehan, S., Bauer, R. B., and Meyer, J. S. (1960). Neurology (Minneap.), 10, 968.

Wells, C. E. (1960). Arch. Neurol. (Chic.), 3, 319.

Williams, D. (1961). In Scientific Aspects of Neurology, edited by H Garland, p. 202. Livingstone, Edinburgh.

- and Wilson, T. G. (1962). Brain, 85, 741

\title{
Proteins of Serum and Oedema Fluid in Rheumatoid Arthritis
}

\author{
DOROTHY C. PARK,* M.SC.; K. SWINBURNE,* M.B., B.CHIR.
}

Brit. med. F., 1964, 1, 86-88

Oedema occurs in many conditions and can usually be explained on the basis of sodium retention, increased filtration pressure, lymphatic insufficiency, reduced plasma osmotic pressure, or increased capillary permeability. The cause of the oedema which occurs quite often in rheumatoid arthritis has not yet been established.

Crockett (1956) measured the protein levels of oedema fluid in several diseases and on the basis of his results he was able to classify the causes of oedema into three distinct categories. This is shown in Table I. The third class of oedema, which is that due to increased permeability of the

$$
\begin{aligned}
& \text { TABle I.-Classification of Oedema According to Protein Level } \\
& \text { (Crockett, 1956) } \\
& \text { Cause of Oedema } \\
& \text { Protein Level of } \\
& \text { Oedema Fluid } \\
& \text { (g./100 ml.) }
\end{aligned}
$$

capillary endothelium, occurs in inflammatory conditions, including burns and scalds, and in allergic reactions. It was thought possible that the oedema of rheumatoid arthritis might also be caused by increased capillary permeability, resulting either from the inflammatory nature of the underlying disease or from tissue responses of an allergic type. The protein levels and electrophoretic pattern of oedema fluid in rheumatoid arthritis have not previously been reported. This information, together with a knowledge of the relative sizes of the different protein fractions, should make it possible to decide whether or not the oedema is due to increased capillary permeability.

In the subacute and chronic phases of rheumatoid arthritis, oedema is most prominent in the region of the feet and ankles.

\section{Material}

Specimens of oedema fluid were obtained from the subcutaneous tissues by acupuncture. In order to avoid dilution of the fluid a local anaesthetic was not used, and the discomfort was only slight. There was difficulty in obtaining specimens which were uncontaminated with blood, and it was usually impossible to do more than introduce the tip of a Southey tube under the skin. Any attempt to pass the tubes full length, in the usual way, nearly always provoked bleeding. Since attempts at acupuncture were limited to two per patient the number of specimens obtained was restricted. A further difficulty was the slow rate of flow from the tubes; even after 15 to 20 minutes' collection the samples were small, usually 0.5 to $1 \mathrm{ml}$. - From the Departments of Chemical Pathology and Clinical Medicine, 
Oedem ftrids were collected from two : groups of patients who had swelling of the feet and ankles. The first group consisted of 18 patients with rheumatoid arthritis, the diagnostic criteria being those of the American Rheumatism Association (Ropes, Bennett, Cobb, Jacox, and Jessar, 1956, 1958). Sixteen had uncomplicated rheumatoid arthritis, one had rheumatoid arthritis and systemic lupus erythematosus, and one had rheumatoid arthritis and amyloid disease. The second group consisted of three patients, of whom two had congestive heart failure and one had oedema of hemiplegia. These three cases were included in the series for the sake of comparison.

Blood was also collected so that the electrophoretic pattern of each specimen of oedema fluid could be compared with that of the serum from the same patient.

\section{Methods}

The total protein content of the oedema fluid was estimated turbidimetrically by the method of Kingsbury, Clark, Williams, and Post (1926).

Electrophoresis of oedema fluid and serum was carried out on cellulose acetate membrane, according to the technique described by Kohn (1958a). As a supporting medium for zone electrophoresis cellulose acetate has several advantages over filter paper, and the outstanding advantage in the present study was that very small quantities of protein could be analysed. The total protein content of the oedema fluids was so low, and the volume of the specimens was so small, that these studies would not have been possible with the usual paper-electrophoresis techniques.

The cellulose acetate strips used were 10 by $2.5 \mathrm{~cm}$. Usually about $5 \mu \mathrm{l}$. of the sample was applied, but the amount was varied to accommodate different concentrations of protein. Good separation of the protein fractions was obtained in one hour, using a constant current of $1 \mathrm{~mA}$ per strip.

The serum proteins and, where concentration was adequate, the oedema-fluid proteins were stained with lissamine green. When it was not possible to demonstrate the pattern of the oedema-fluid proteins with lissamine green the strips were overstained with nigrosin, which is a more sensitive stain recommended for this purpose (Kohn, 1958b).

The electrophoretic patterns were interpreted by visual inspection, which gave sufficient information for this investigation.

\section{Total Protein Content of the Oedema Fluid}

The results obtained for the oedema-fluid total protein are shown in Table II. In patients with uncomplicated rheimint toid arthritis the protein content of oedema fluid wast normally below $1 \mathrm{~g} . / 100 \mathrm{ml}$. (mean 0.59). In the two cases of rheumatoid arthritis with complications the results show holy

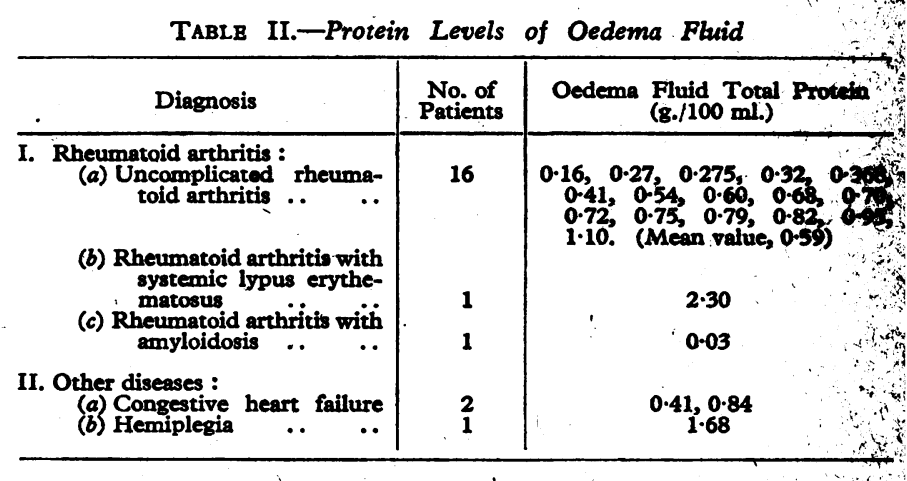

a multiple pathological condition can alter the protein leveks Both patients with congestive heart failure had oedema-flitil proteins less than $1 \mathrm{~g} . / 100 \mathrm{ml}$. The patient with hemiplegit had a higher protein content, $1.68 \mathrm{~g} . / 100 \mathrm{ml}$.

\section{Comparison of the Electrephoretic Pattern of Oedema-fan Proteins with that of Serum Proteins}

The electrophoretic pattern of serum proteins is known be altered in rheumatoid arthritis (Ropes, Perimans, Kaufman, and Bauer, 1954). There is usually an increase in alpha $_{2}$ and gamma-globulins and often a diminution in albumin.

Fig. 1 shows the electrophoretic patterns of a normal sernin and of sera from two patients with rheumatoid arthritis. The first abnormal serum shows a diminution in albumin, at increase in alpha, and gamma-globulins, and a very martod increase in alpha ${ }_{2}$-globulin. In the second abnormal seruin there is a diminution in albumin and a less marked but stifl definite increase in alpha $\mathrm{a}_{2}$-globulin.

In each patient with rheumatoid arthritis comparison of thet protein pattern of the serum with that of the oedema findid
FIG. 1

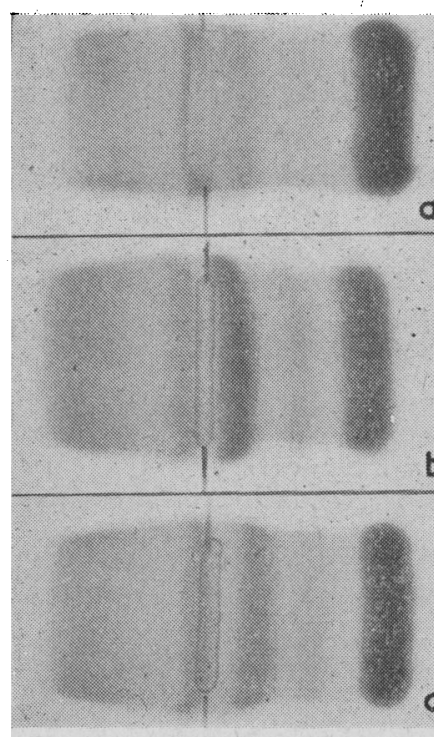

FIG. 2

FIG. 3

FIG. 4

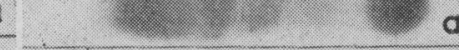


showed a consistent difference in protein distribution. This is illustrated in Fig. 2, in which the serum proteins are stained with lissamine green and the oedema-fluid proteins with nigrosin. The serum shows a diminution in albumin and an increase in all globulins, especially alpha $a_{2}$ and gammaglobulins. The increased serum gamma-globulin is reflected in the oedema fluid, but the increase in serum alpha $a_{2}^{-}$ globulin is not reflected in the oedema fluid. In fact, there is a relative diminution of the alpha $_{2}$ fraction in the oedema fluid. On the other hand, the alpha,-globulin fraction shows a relative increase in the oedema fluid. There is also a much higher proportion of albumin in the oedema fluid than in the serum, although this is not so apparent in Fig. 2 because the nigrosin stain has a very nonlinear protein-dye uptake curve (see Fig. 4).

The serum and oedema-fluid patterns of a patient with congestive heart failure are shown in Fig. 3. Here the relative distribution of the different protein fractions is entirely like that observed above in rheumatoid arthritis.

Fig. 4 shows the distribution of proteins in the serum and oedema fluid of a patient with hemiplegia. The serum pattern is almost normal, with only a slight increase in the alpha ${ }_{2}$-globulin. The first oedema-fluid pattern is stained with lissamine green, which is a stain with a linear proteindye uptake curve (Park, 1959), and shows that there is a much higher ratio of albumin to globulins in the oedema fluid than in the serum. In the bottom strip, in which the proteins have been stained with nigrosin, this fact is not so evident because of the non-linear dye-protein relationship. Fig. 4 thus illustrates the need for caution in interpreting strips stained with nigrosin.

\section{Discussion}

The proteins of oedema fluid from patients with rheumatoid arthritis have not previously been investigated. The low total protein content reported here suggests that we are not dealing with an inflammatory or allergic exudate. The protein levels are normally below $1 \mathrm{~g} . / 100 \mathrm{ml}$, and so the oedema of rheumatoid arthritis belongs to group 1 of Crockett's classification of oedema shown in Table I. In this group, which includes congestive heart failure, venous obstruction, and hypoproteinaemia, oedema is due to disturbance of the filtration-absorption equilibrium.

Therefore it would appear that the oedema fluid in rheumatoid arthritis is a transudate. In other words, it is a filtrate from a capillary endothelium which has a normal selective permeability to protein. Such a filtrate would be expected to contain more small-sized protein molecules and fewer large-sized protein molecules than the serum from which it is derived. This is supported by the results of electrophoresis.

The albumin and alpha ${ }_{1}$-globulin fractions contain relatively small serum protein molecules, and electrophoresis shows that the oedema fluid contains relatively more of these two fractions than does the serum. Hammond (1961) also found this to be the case when he investigated the proteins of serum and oedema fluid in anoxic cor pulmonale.

The alpha $a_{2}$-globulin fraction, on the other hand, contains relatively large protein molecules, and although this fraction is notably increased in serum in rheumatoid arthritis it is diminished in the oedema fluid. Similarly, Exton-Smith and Crockett (1957) found that in oedema associated with conditions in which capillary permeability is believed to be

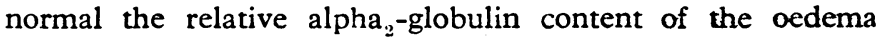
fluid was always much less than in serum.

Gamma-globulin, which is intermediate in size between alpha ${ }_{1}$ - and alpha $a_{2}$-globulin, is increased in the oedema fluid only when it is increased in the serum.

This distribution of large and small protein molecules on either side of the capillary endothelium shows that in rheumatoid arthritis the membrane maintains a normal selective permeability. There is thus no evidence to support the suggestion that the oedema seen in rheumatoid arthritis is inflammatory or allergic in origin. The above investigation does not, however, define the exact mechanism responsible for the formation of the oedema fluid, and this will be discussed in a subsequent communication.

\section{Summary}

A study is described of the proteins of serum and oedema fluid from patients with rheumatoid arthritis. Oedema fluid from patients with uncomplicated rheumatoid arthritis has 2 low total protein content. Electrophoresis of serum and oedema-fluid proteins shows that in the oedema fluid there is a relative increase in the concentration of smaller protein molecules and a relative decrease in the concentration of larger protein molecules. These findings indicate that in rheumatoid arthritis the capillary endothelium has a normal selective permeability to "protein and therefore that the oedema is not of inflammatory or allergic origin.

Our thanks are due to Professor S. J. Hartfall for bis suggestion that we should undertake this investigation, and to Professor G. H. Lathe for his advice and interest.

\section{REFERENCES}

Crockett, D. J. (1956). Lancet, 2, 1179.

Ex:on-Smith, A. N., and Crockett, D. J. (1957). Brit. med. Y., 2, 1280.

Hammond, J. D. S. (1961). Lance, 1, 136.

Kingsbury, F. B., Clark, C. P., Williams, G., and Post, A. L. (1926). f. Lab. clin. Med., 11, 981 .

Kohn, J. (1958a). Clin. chim. Acta, 3, 450.

- (1958b). Naiure (Lond.), 181, 839.

Park, D. C. (1959). M.Sc. Thesis, University of Durham.

Ropes, M. W., Benne:t, G. A., Cobb, S., Jacox, R., and Jessar, R. A. (1956). Bull. rheum. Dis., 7, 121.

- _ _ (1958). Ibid., 9, 175.

Perlmann, G. E., Kaufman, D., and Bauer, (1954). 7. clin. Invest., 33, 311. 